\title{
Design and selection of facility layout using simulation and design of experiments
}

\author{
R. Jayachitra and P. S. S. Prasad \\ Department of Mechanical Engineering, PSG College of Technology, Coimbatore-641004, India \\ jayachitra_cbe@yahoo.co.in; pssai@yahoo.com
}

\begin{abstract}
In the global industrial competition, layout design and planning is becoming more and more critical due to shorter product life cycles and highly dynamic demand conditions. In this context, traditional layouts such as product and process/functional layouts are considered inferior. Cellular layouts have been proposed as an alternative to these layouts but they need a complete reallocation of resources, which consumes time and money. Hence, it is necessary to verify the performance measures before the design and selection of a certain type of layout. In this context, this paper makes an attempt to study the suitability of a virtual cellular layout (VCL) along with an existing functional layout (FL) of an industry and a classical cellular layout (CL), if considered for implementation. A Genetic algorithm (GA) based intracell formation procedure is used in the cellular layout design. To identify the suitability of a particular layout in a given environment, a typical manufacturing system is modeled using the WITNESS 2006 simulation software. Design of experiments (DOE) is used to plan the simulation experiments. The performance of each of the three layouts is analyzed statistically by means of operational parameters such as machine utilization, throughput, average distance traveled by parts and average work-in-process. The results from the simulation experiments indicate that the performance of virtual cellular manufacturing falls between that of functional and cellular manufacturing. Also, we find that the performance of a virtual cellular layout is often relatively superior to that of a functional layout and marginally inferior to a cellular layout.
\end{abstract}

Keywords: Functional layout, cellular layout, virtual cellular layout, genetic algorithm, simulation.

\section{Introduction}

In the global industrial environment, it is essential that manufacturing systems should be controlled optimally, to minimize manufacturing costs, to meet production schedules and to improve productivity. Suresh (1992) has demonstrated that, the traditional layout types such as process layout and product layout do not have the ability to respond quickly to the changes in product mix. In recent years, manufacturing organizations have been unable to cope with an increasingly fast changing market. Product life cycles tend to be much shorter than in the past; this forces manufacturing organizations to increase responsiveness and flexibility, and to shorten setup times and lower work-in-process inventory while maintaining an acceptable efficiency level. Cellular manufacturing is a successful application of group technology (GT) concepts. Luong et al. (1997) stated that the cellular manufacturing system (CMS) is an efficient concept for improving the productivity of batch production systems. The aim of a CMS is to identify similar manufacturing processes and features, where machines are grouped into machine cells based on their contributions to the production process. Kannan and Ghosh (1996) showed that the issue in implementing CMS is the rearrangement cost of resources (particularly machines) based on the change in product mix over a time period. If the companies are interested in implementing manufacturing systems that can be quickly reconfigured with almost negligible equipment rearrangement costs, then a virtual cellular manufacturing (VCM) system can be considered as a viable option. McLean et al. (1982) stated that virtual manufacturing cells are the logical groups, where facilities are not relocated physically. Facilities are placed based on the functionality and routing of parts is obtained by cell formation algorithms in a functionally organized virtual cell. Fluctuation in demands and changes in part varieties can be accommodated through virtual manufacturing cells. Implementation of VCM requires the dedication of individual machines within a department to a specific product family. Kannan and Ghosh (1996) proved that VCM helps to maintain the manufacturing system efficiently even for unpredictable demands and changes in product mix. They stated that, due to the dynamic nature of VCM, it is expected to be superior to a CMS in terms of efficiency, cost, and resource utilization. Process and cellular layouts

A process layout is a physical and organizational arrangement where equipment and processes performing identical or similar operations are grouped and located in physical proximity. A cellular layout, on the other hand, is an arrangement of one or more independent or linked cells. A cell is an organizational unit where a group of dissimilar equipment or processes are put in close proximity and dedicated to a family of parts or products. Greene and Sadowski (1984) stated that a process layout is associated with high machine utilization and shop flexibility. Flynn and Jacobs (1987) showed that in both process and cellular layouts, permanent machine
Research article

CIndian Society for Education and Environment (iSee)
"Virtual cellular layout" http://www.indjst.org
Jayachitra \& Prasad Indian J.Sci.Technol. 
dedication yielded poor flow time and queue-related performance. They observed that this was due to the dedication of equipment rather than the layouts themselves which causes difference in performance between process and cellular layouts. Morris and Tersine (1990) used simulation to show that a cellular layout outperform a process layout by considering a set of conditions, namely high set-up and material handling times and stable demand patterns. Mahmoodi et al. (1990) made an attempt to overcome the limitations of cellular manufacturing by using scheduling rules to process the jobs with similar set-up requirements. Suresh (1992) demonstrated analytically the deterioration in shop performance when a process layout is converted to a cellular layout. Shiba et al. (1993) brought out the benefits of cellular manufacturing which includes faster throughput times, improved product quality, lower work-in-process (WIP) levels and reduced set-up times. Saad and Lassila (2006) proposed an integrated methodology for shop floor configuration to assess and compare layouts for a typical random machine arrangement and to evaluate the effectiveness of the product flow optimization process. Balakrishnan and Hung Cheng (2007) addressed cellular manufacturing systems under conditions of multi-period planning horizons with demand and resource uncertainties.

The next part of the literature review addresses research contributions toward virtual cellular layouts. McLean et al. (1982) defined a virtual cell as a logical grouping of workstations that remains in the same position as the process layout unlike physical proximity as in a cellular layout. Virtual cellular layouts are designed as a temporary grouping of machines, jobs and workers to realize the benefits normally associated with Cellular layouts. Drolet et al. (1989; 1990 \&1995) studied VCM concepts and developed algorithms for scheduling virtual cells to establish their high set-up efficiency without losing the flexibility of a functional layout. Irani et al. (1993) showed that virtual cells can minimize load balancing problems that arise due to sharing of machines by various part families. Kannan and Ghosh (1996) showed that the benefits of CMS can be improved by dedicating machines to part families on a temporary basis, and allowing cells to respond to changes in the existing shop conditions. They also stated that VCM is an alternative between the extremes of high flexibility/low set-up efficiency (process layout) and low flexibility/high set-up efficiency (cellular layout). Waterson et al. (1999) studied industrial cases regarding parallel machine shops for implementing the concept of virtual cellular manufacturing for production control. Subash Babu et al. (2000) remarked that, VCMs ensure most of the benefits of CMS without physical relocation of existing manufacturing resources. Hyer and Wemmerlöv (2002) stated that VCMs are often considered as feasible alternatives for CMS in improving shop performance. Wemmerlöv and Jonson (2004) stated that the implementation of cellular manufacturing is often not feasible in practice, for financial and technical reasons. Mak et al. (2007) proposed an ant colony optimization algorithm for designing virtual cellular manufacturing systems. Nomden and van der Zee (2008) addressed VCM for their increased routing flexibility by the distribution of alternative machines for a product family. Peng et al. (2009) proposed a two-stage mathematical approach to design VCMs that optimize the number of part families and the number of shared machines. Kesen et al. (2009) compared process, cellular and virtual cellular layouts using simulation and indicated that virtual cells have better responsiveness in terms of mean flow time and mean tardiness.

\section{Cell formation}

Chandrasekharan and Rajagopalan (1986 a;b) conducted a survey of various approaches to identify cell systems for grouping part families and machine types. Stanfel (1989) suggested that the best advantage of GT must be gained by minimizing the inter-cell transfers. Harhalakis et al. (1990) proposed a simple two fold heuristic algorithm that is capable of minimizing intercellular material movement. An attempt was also made to maximize the total intra-cellular traffic in the system by converting the inter-cell traffic into intra-cell traffic. A perfect grouping may not be possible in all cases. A part may have to visit more than one cell to complete its processes. Vakharia and Wemmerlov (1990) proposed a cell formation approach that identifies cells, based on material flows which are usually represented by operation sequences (part routings). Srinivasan et al. (1990) developed an assignment model to solve the grouping problem.

A similarity coefficient matrix is used as an input to the assignment problem. Rajamani et al. (1990) developed three integer programming models to form part families and machine groups by taking into account of alternative process plans. Song and Hitomi (1992) addressed inter-cell transfer in which the methodology proposed by them for the design of a GT cell offered a capability of minimizing the total inter-cell flow of parts in the system. Venugopal and Narendran (1992) proposed a bi-criteria mathematical model with a solution procedure based on genetic algorithm for a cellular manufacturing environment. Rajamani et al. (1996) developed a mixed integer program model for the design of cellular manufacturing systems. The objective of the model is to minimize the sum of investment, processing and material handling costs. Souilah et al. (1996) proposed a procedure to solve four modules problem which consists of data analysis, cell design, cell layout design (material handling selection and intra-cell layout design) and Intercell layout design. Baykssoglu and Gindy (2000) developed a pre-emptive goal programming for forming independent part/machine cells that takes care of operation sequences, processing times, capacities, demand, cell sizes, cell flexibility, load balance between cells, cell interaction and copies of each machine type in
Research article

CIndian Society for Education and Environment (iSee)
"Virtual cellular layout" http://www.indjst.org
Jayachitra \& Prasad Indian J.Sci.Technol. 
Indian Journal of Science and Technology

Table 1. Process plan for model 1 submersible pump

\begin{tabular}{|c|c|c|c|c|}
\hline Part name & $\begin{array}{l}\text { Qty/ } \\
\text { pump }\end{array}$ & $\begin{array}{c}\text { Op. } \\
\text { no }\end{array}$ & $\mathrm{M} / \mathrm{C}$ used & $\begin{array}{c}\text { Cycle } \\
\text { time } \\
\text { (min) }\end{array}$ \\
\hline \multirow{2}{*}{ Suction Housing (P1) } & \multirow{2}{*}{1} & 1 & Centre Lathe (L8) & 18.4 \\
\hline & & 2 & Drilling machine (D2) & 8 \\
\hline \multirow{3}{*}{ Stage Casing (P2) } & \multirow{3}{*}{8} & 1 & Centre Lathe (L3) & 4.84 \\
\hline & & 2 & Centre Lathe (L4) & 4.84 \\
\hline & & 3 & Drilling machine (D3) & 3.42 \\
\hline \multirow{2}{*}{ Discharge outlet (P3) } & \multirow[b]{2}{*}{1} & 1 & Centre Lathe (L1) & 24 \\
\hline & & 2 & Centre Lathe (L8) & 15 \\
\hline \multirow{2}{*}{ NRV Body (P4) } & \multirow{2}{*}{1} & 1 & Centre Lathe (L7) & 40 \\
\hline & & 2 & Drilling machine (D2) & 4.17 \\
\hline NRV Cone (P5) & 1 & 1 & Centre Lathe (L3) & 24 \\
\hline \multirow{2}{*}{ Impeller (P6) } & \multirow{2}{*}{8} & 1 & Broaching machine (BR) & 3.5 \\
\hline & & 2 & Balancing machine (BA) & 4.0 \\
\hline Thrower (P7) & 1 & 1 & Centre Lathe (L2) & 8.57 \\
\hline Locking Cap (P8) & 1 & 1 & Centre Lathe (L3) & 8.57 \\
\hline NRV Cone Stem (P9) & 1 & 1 & Centre lathe (L5) & 22.86 \\
\hline \multirow{2}{*}{$\begin{array}{l}\text { Distance Sleeve } \\
\text { (P10) }\end{array}$} & & 1 & Grinding machine (G1) & 2.5 \\
\hline & & 2 & Broaching machine (BR) & 3.5 \\
\hline \multirow{2}{*}{ DOL Sleeve (P11) } & \multirow{2}{*}{1} & 1 & Grinding machine (G1) & 2.5 \\
\hline & & 2 & Broaching machine (BR) & 3.5 \\
\hline \multirow{4}{*}{ Pump shaft (P12) } & \multirow{4}{*}{1} & 1 & Centre lathe (L1) & 60 \\
\hline & & 2 & Centre lathe (L6) & 5.51 \\
\hline & & 3 & Milling machine (M1) & 39.14 \\
\hline & & 4 & Grinding machine (G1) & 52 \\
\hline
\end{tabular}

cell type system design and solved through clustering algorithm. Ahi et al. (2009) applied a multiple attribute decision making concept and proposed a two-stage method that leads to determine cell formation, intracellular machine layout and cell layout which offers good solutions for the cellular manufacturing system. Sofianopoulou (2010) proposed genetic algorithm approach for cell formation problem with the objective of minimizing the inter-cellular traffic subject to cell size constraints. Durán et al. (2010) proposed a modified particle swarm optimization algorithm to address the problem of manufacturing cell formation. The proposed algorithm, the concept of proportional likelihood with modifications, a technique of data mining applications is used. The criterion used to group the machines into cells is based on the minimization of inter-cell movements.

This study is an attempt in making the specific choice between process, cellular and virtual cellular layouts in terms of performance metrics such as machine utilization, throughput, average distance traveled by parts and average work-inprocess through simulation based experimentation

the shop. The model is solved through specially developed tabu search algorithm. Adil and Rajamani (2000) studied cell compactness and cell independence in terms of inter-cell and intra-cell move costs. They developed a nonlinear programming model and used simulated annealing algorithm to minimize the total intracell and inter-cell movement costs. This paper also made an attempt to improve the intra-cell design using genetic algorithm. Jeffrey Schaller (2005) compared the procedures that generate heuristic solutions for a cell formation problem. The objective of the model is to minimize cost, which includes the cost of intra-cell and inter-cell moves, and the cost of the equipment used in the cells. Wei and Mejabi (2008) developed a non-linear integer programming formula to reduce inter-cell trips in a for the given situation.

\section{Data collection}

The following are the data collected from a pump manufacturing industry. It includes the machine details, location of machines, parts produced, part routings, processing times, setup time details, batch sizes etc. The industry is a typical job shop consisting of eighteen machines of six types. Twenty different parts are processed on these machines. The parts are produced according to operational sequences specified in their process sheet (Table $1 \& 2$ ).

\section{Experimental design}

Jobs are processed on first in first out (FIFO) basis. Other than FIFO, the rules like shortest processing time Table 2. Process plan for model 2 submersible pump

\begin{tabular}{|c|c|c|c|c|}
\hline Part name & $\begin{array}{l}\text { Qty/ } \\
\text { pump }\end{array}$ & $\begin{array}{l}\text { Op. } \\
\text { no }\end{array}$ & $M / C$ used & $\begin{array}{c}\text { Cycle } \\
\text { time }(\min )\end{array}$ \\
\hline \multirow{2}{*}{ Impeller (P13) } & \multirow{2}{*}{8} & 1 & Broaching machine(BR) & 3.5 \\
\hline & & 2 & Balancing machine (BA) & 4.0 \\
\hline \multirow{2}{*}{$\begin{array}{l}\text { Suction } \\
\text { Housing (P14) }\end{array}$} & \multirow{2}{*}{1} & 1 & Centre lathe (L8) & 18.46 \\
\hline & & 2 & Drilling machine (D1) & 6.85 \\
\hline \multirow{2}{*}{$\begin{array}{l}\text { Stage Casing } \\
\text { (P15) }\end{array}$} & \multirow{2}{*}{8} & 1 & Centre Lathe (L7) & 26.67 \\
\hline & & 2 & Drilling machine (D1) & 10.86 \\
\hline \multirow{2}{*}{ NRV body (P16) } & \multirow{2}{*}{1} & 1 & Centre Lathe (L8) & 34.28 \\
\hline & & 2 & Drilling machine (D1) & 6.00 \\
\hline \multirow{2}{*}{$\begin{array}{l}\text { Distance Sleeve } \\
\text { (P17) }\end{array}$} & \multirow{2}{*}{1} & 1 & Grinding machine (G2) & 2.5 \\
\hline & & 2 & Milling machine (M2) & 2.5 \\
\hline NRV Cone(P18) & 1 & 1 & Centre lathe (L4) & 25.26 \\
\hline NRV Stem(P19) & 1 & 1 & Centre lathe (L5) & 20.87 \\
\hline \multirow{4}{*}{$\begin{array}{l}\text { Pump Shaft } \\
\text { (P20) }\end{array}$} & \multirow{4}{*}{1} & 1 & Centre lathe (L2) & 12 \\
\hline & & 2 & Centre lathe (L9) & 66 \\
\hline & & 3 & Milling machine (M2) & 24 \\
\hline & & 4 & Grinding machine (G2) & 40 \\
\hline
\end{tabular}

(SPT) and longest processing time (LPT) are considered for the study. Machines need to be setup before each operation. In case of cellular layout and virtual cellular layout two types of setup time are considered namely major setup times and minor setup times. Major setups occur when there is a change in the family being processed on a machine. Minor setups occur when there is a change in the part being processed on a machine but there is no change in the family being processed. The demand for a month is forecasted as ninety using adjusted exponential smoothing and the same is used for calculating the lot size. Three demands namely current demand, $20 \%$ increase over current demand and $50 \%$ increase over current demand are taken and lot sizes are calculated by dividing the demand with the simulation period. Thus three lot sizes of 4,5 and 6

Research article

CIndian Society for Education and Environment (iSee)
"Virtual cellular layout" http://www.indjst.org
Jayachitra \& Prasad Indian J.Sci.Technol. 
Indian Journal of Science and Technology

Fig. 1. Process layout - Simulation model

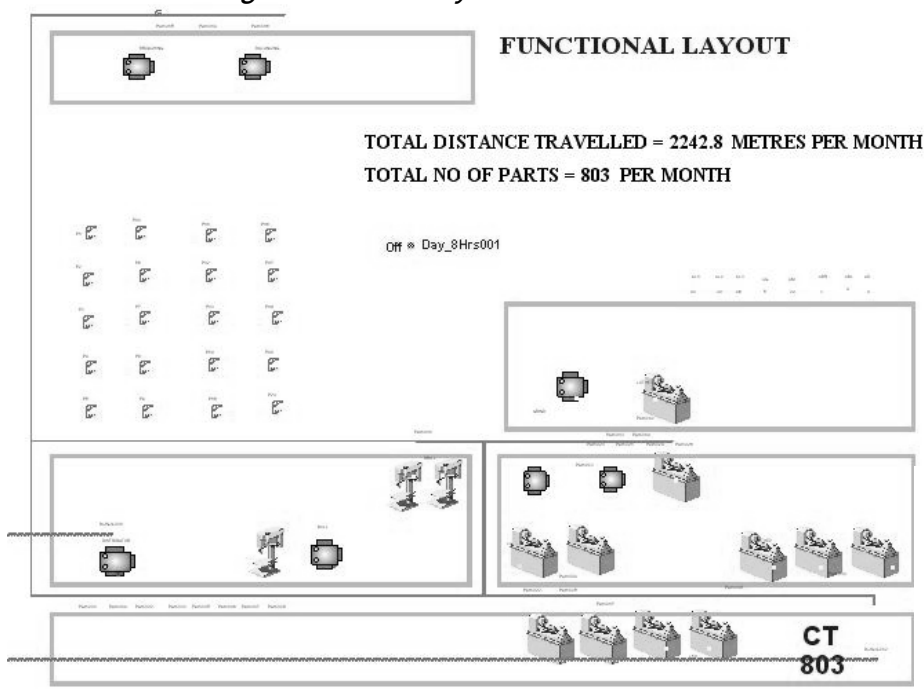

Vol. 3 No. 4 (Apr. 2010)

ISSN: 0974- 6846

Fig. 2. Layout of chromosome $\{52134\}$
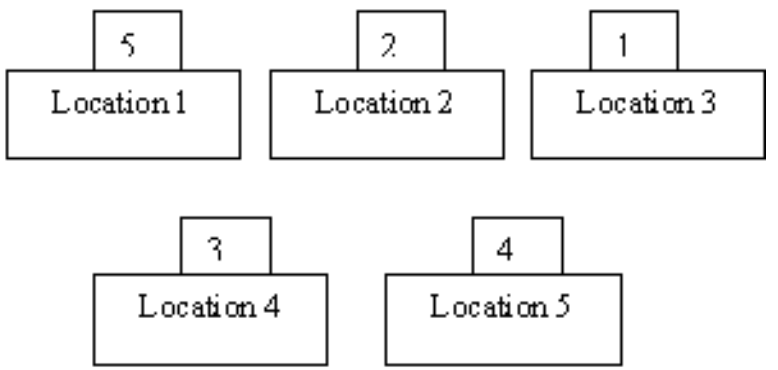

Fig. 3. Initial design of cell 1

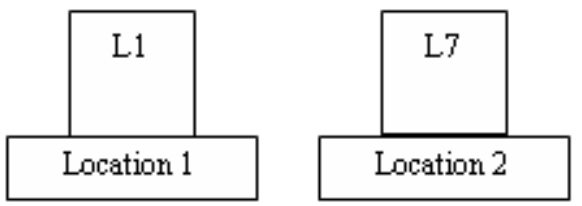

Fig. 4. Initial design of cell 2

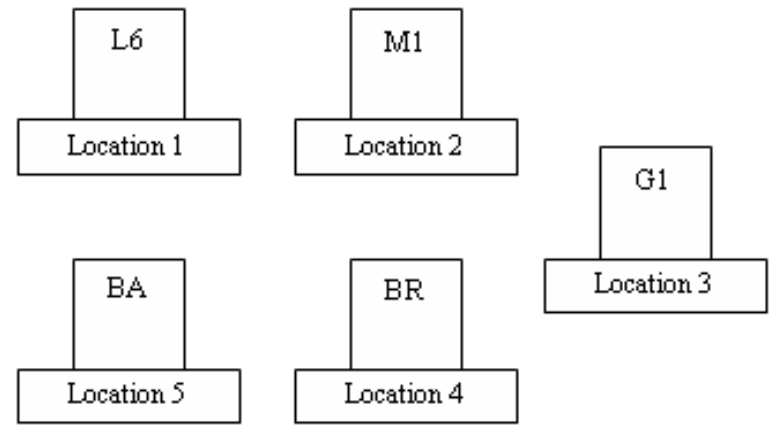

Fig. 5. Initial design of cell 4

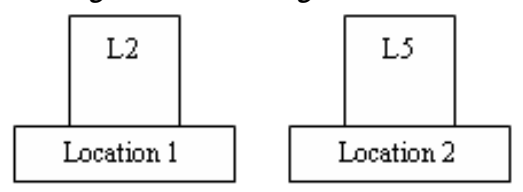

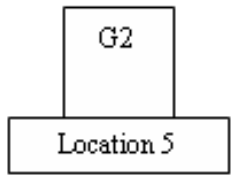
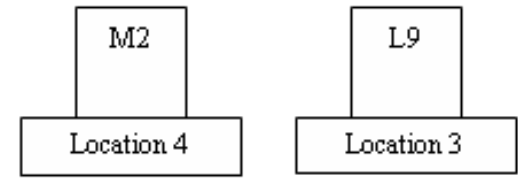

Fig. 7. Virtual cellular layout - Simulation model

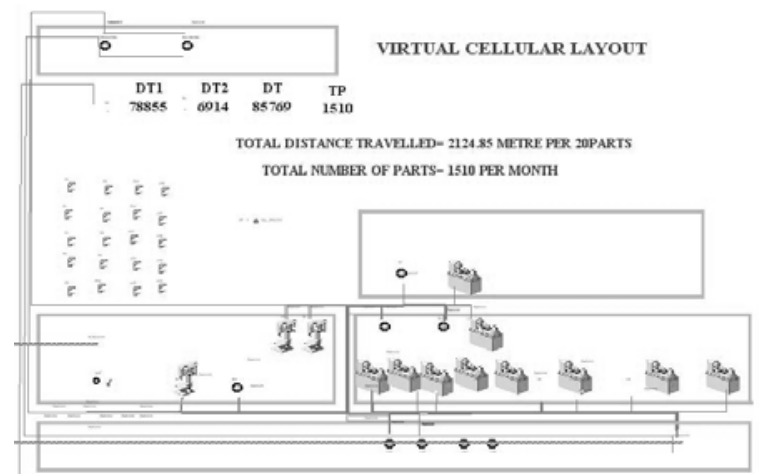

Research article

CIndian Society for Education and Environment (iSee)
"Virtual cellular layout" http://www.indjst.org
Fig. 8. Interaction plot for \% machine utilization

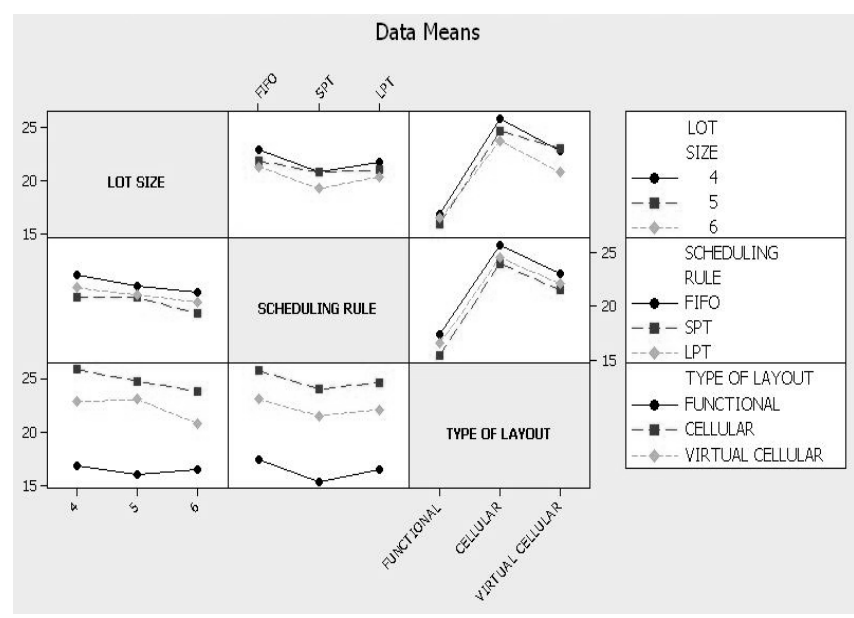

Fig. 6. Cellular layout - Simulation model

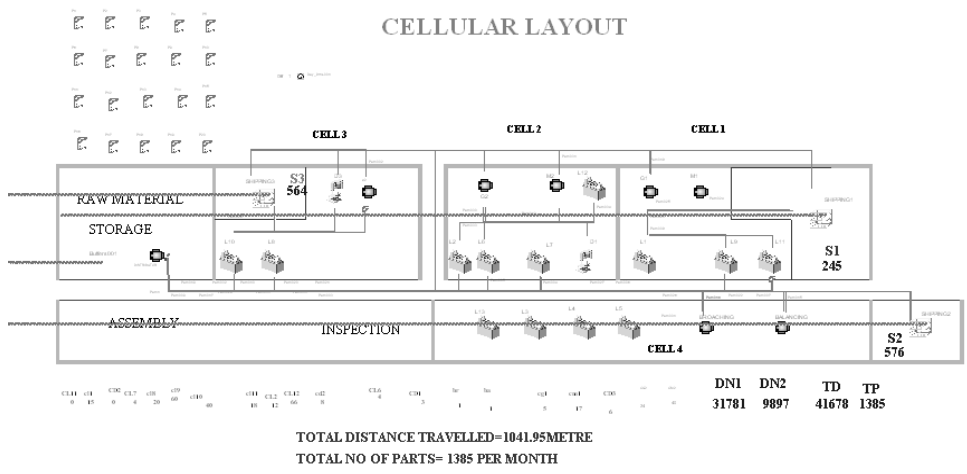

TOTAL DISTANCE TRAVELLED=1041.95METR

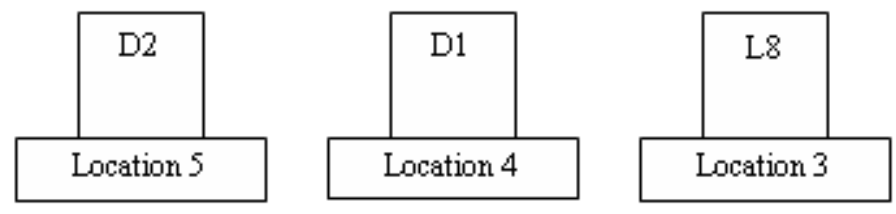


Table 3. Factors and levels for design of experiments

\begin{tabular}{|c|l|c|c|c|}
\hline \multicolumn{2}{|c|}{} & \multicolumn{3}{|c|}{ Levels } \\
\hline \multirow{4}{*}{ Factors } & $\begin{array}{c}\text { Scheduling } \\
\text { rule }\end{array}$ & $\begin{array}{c}\text { FIFO } \\
\text { (first in } \\
\text { first out) }\end{array}$ & $\begin{array}{c}\text { SPT } \\
\text { (shortest } \\
\text { processing } \\
\text { time) }\end{array}$ & $\begin{array}{c}\text { LPT } \\
\text { (longest } \\
\text { processing } \\
\text { time) }\end{array}$ \\
\cline { 2 - 5 } & Lot size & 4 & 5 & 6 \\
\cline { 2 - 5 } & $\begin{array}{l}\text { Type of } \\
\text { layout }\end{array}$ & $\begin{array}{c}\text { Process / } \\
\text { functional }\end{array}$ & Cellular & $\begin{array}{c}\text { Virtual } \\
\text { cellular }\end{array}$ \\
\hline
\end{tabular}

are obtained and used as a factor in DOE. Simulation runs are conducted based on the parameters and their levels. Twenty seven experiments according to full factorial experimentation are carried out.

\section{Model building \& simulation}

The simulation models of process, cellular and virtual cellular layouts for all twenty seven experiments are built using WITNESS 10.0. The simulation period considered is one month, with 25 working days and one shift of 8 hours per day.

\section{Simulation of process layout}

The existing layout of the industry is modeled as per the locations of the machines in the shop floor. The parts are assigned to the available machine among the identical machines as per its process requirement. The parts will go through all the required operations as per the scheduling rule of the experiment and it will move in the same sequence through various functional departments. After completion of all the operations, parts leave the system. Simulation model of process layout is shown in Fig. 1.

\section{Cell formation}

In cellular and virtual cellular layouts, initial part machine matrix is formed based on the machine requirement by parts shown in Table 4. Manufacturing cells and part families are formed using rank order clustering algorithm (ROC) (King, 1980). ROC algorithm seems to be a feasible alternative compared to other algorithms which give better results for a wide range of data varying from $100 \times 25$ to $20,000 \times 200$ (Kaparthi \& Suresh 1994). Table 5 shows the details of machines belonging to each cell based on ROC algorithm.

\section{Intra-cell design for cellular layout using genetic algorithm}

In the design of cellular manufacturing systems, the goal is to partition machines into cells so that the travel distance of part is minimized. The intra-cell travel distance of part is affected by the locations of machines within the cell. Since the cost associated with the layout is proportional to the distance traveled by the parts, the algorithm has the objective of minimizing the intra-cell distance traveled by the parts. In the formulation, the cost of material handling per unit distance is assumed to be constant. Genetic algorithm is an adaptive search technique which imitates the process of biological evolution. To reduce the intra-cell movement of parts, a program has been written using $\mathrm{C}++$ with the help of genetic algorithm. The objective of this program is to optimize the arrangement of machines inside the cell. Thus the intra-cell movement of parts and the material handling cost is reduced. The chromosome representation is based on the permutation of integers which represents the machine numbers, where the location of the gene represents the location of the machines. Fig. 2 refers the layout of chromosome 52134. The distances between locations, as well as the possible locations of machines are known in advance. Another important data required for the layout problem is the frequency of part movement between machines, which indicates the number of times a part has to move from one location to another. An initial population of desired size is generated randomly with population size of 10 . GA procedure computes score function for each string of the solution space so that the string with the maximum score function value is determined. The goal of optimization

Fig. 9. Interaction plot for throughput

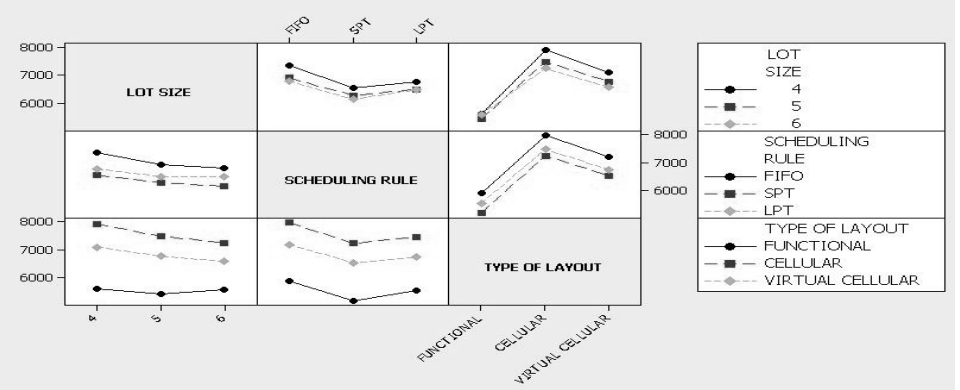

Fig. 10. Interaction plot for distance traveled by parts

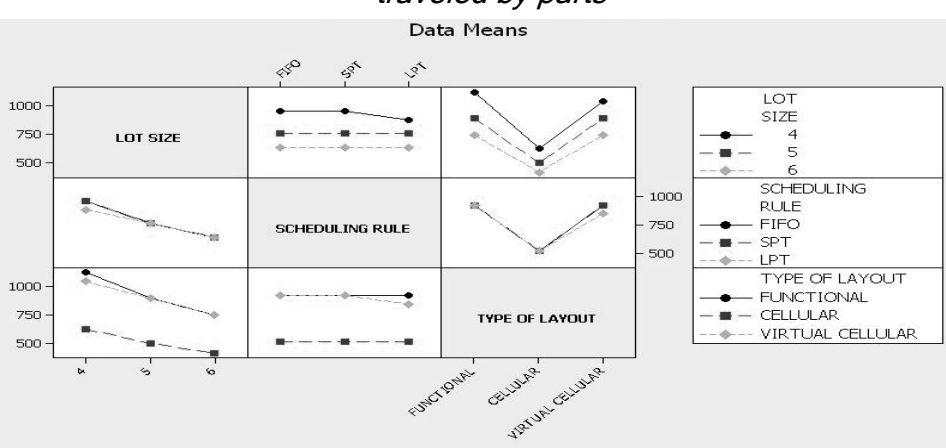

Fig. 11. Interaction plot for average work-in-process Data Means

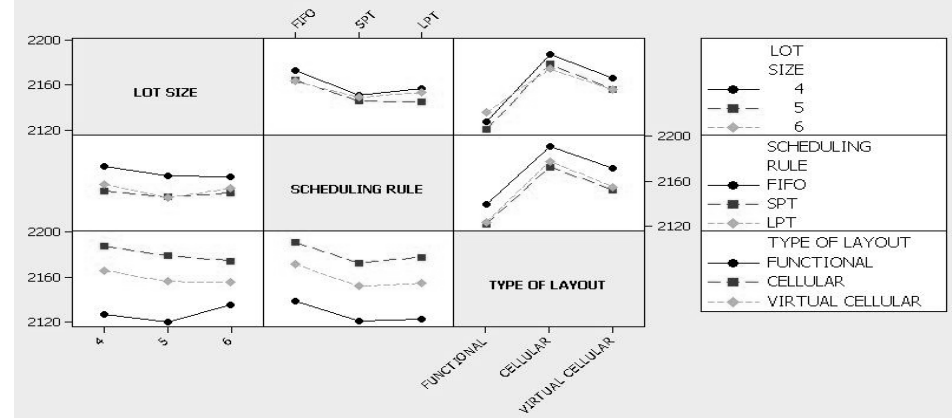

"Virtual cellular layout" http://www.indjst.org
Jayachitra \& Prasad Indian J.Sci.Technol. 
Table 4. Machine part matrix for model $1 \&$ model 2 submersible pumps

\begin{tabular}{|c|c|c|c|c|c|c|c|c|c|c|c|c|c|c|c|c|c|c|}
\hline & $\mathrm{L} 1$ & $\mathrm{~L} 2$ & $\mathrm{~L} 3$ & $\mathrm{~L} 4$ & $\mathrm{~L} 5$ & $\mathrm{~L} 6$ & $\mathrm{~L} 7$ & $\mathrm{~L} 8$ & $\mathrm{~L} 9$ & $\mathrm{D} 1$ & $\mathrm{D} 2$ & $\mathrm{D} 3$ & $\mathrm{M} 1$ & $\mathrm{M} 2$ & $\mathrm{G} 1$ & $\mathrm{G} 2$ & $\mathrm{BR}$ & $\mathrm{BA}$ \\
\hline $\mathrm{P} 1$ & 0 & 0 & 0 & 0 & 0 & 0 & 0 & 1 & 0 & 0 & 1 & 0 & 0 & 0 & 0 & 0 & 0 & 0 \\
\hline P2 & 0 & 0 & 1 & 1 & 0 & 0 & 0 & 0 & 0 & 0 & 0 & 1 & 0 & 0 & 0 & 0 & 0 & 0 \\
\hline P3 & 1 & 0 & 0 & 0 & 0 & 0 & 0 & 1 & 0 & 0 & 0 & 0 & 0 & 0 & 0 & 0 & 0 & 0 \\
\hline P4 & 0 & 0 & 0 & 0 & 0 & 0 & 1 & 0 & 0 & 0 & 1 & 0 & 0 & 0 & 0 & 0 & 0 & 0 \\
\hline P5 & 0 & 0 & 1 & 0 & 0 & 0 & 0 & 0 & 0 & 0 & 0 & 0 & 0 & 0 & 0 & 0 & 0 & 0 \\
\hline P6 & 0 & 0 & 0 & 0 & 0 & 0 & 0 & 0 & 0 & 0 & 0 & 0 & 0 & 0 & 0 & 0 & 1 & 1 \\
\hline P7 & 0 & 1 & 0 & 0 & 0 & 0 & 0 & 0 & 0 & 0 & 0 & 0 & 0 & 0 & 0 & 0 & 0 & 0 \\
\hline P8 & 0 & 0 & 1 & 0 & 0 & 0 & 0 & 0 & 0 & 0 & 0 & 0 & 0 & 0 & 0 & 0 & 0 & 0 \\
\hline P9 & 0 & 0 & 0 & 0 & 1 & 0 & 0 & 0 & 0 & 0 & 0 & 0 & 0 & 0 & 0 & 0 & 0 & 0 \\
\hline P10 & 0 & 0 & 0 & 0 & 0 & 0 & 0 & 0 & 0 & 0 & 0 & 0 & 0 & 0 & 1 & 0 & 1 & 0 \\
\hline P11 & 0 & 0 & 0 & 0 & 0 & 0 & 0 & 0 & 0 & 0 & 0 & 0 & 0 & 0 & 1 & 0 & 1 & 0 \\
\hline P12 & 1 & 0 & 0 & 0 & 0 & 1 & 0 & 0 & 0 & 0 & 0 & 0 & 1 & 0 & 1 & 0 & 0 & 0 \\
\hline P13 & 0 & 0 & 0 & 0 & 0 & 0 & 0 & 0 & 0 & 0 & 0 & 0 & 0 & 0 & 0 & 0 & 1 & 1 \\
\hline P14 & 0 & 0 & 0 & 0 & 0 & 0 & 0 & 1 & 0 & 1 & 0 & 0 & 0 & 0 & 0 & 0 & 0 & 0 \\
\hline P15 & 0 & 0 & 0 & 0 & 0 & 0 & 1 & 0 & 0 & 1 & 0 & 0 & 0 & 0 & 0 & 0 & 0 & 0 \\
\hline P16 & 0 & 0 & 0 & 0 & 0 & 0 & 0 & 1 & 0 & 1 & 0 & 0 & 0 & 0 & 0 & 0 & 0 & 0 \\
\hline P17 & 0 & 0 & 0 & 0 & 0 & 0 & 0 & 0 & 0 & 0 & 0 & 0 & 0 & 1 & 0 & 1 & 0 & 0 \\
\hline P18 & 0 & 0 & 0 & 1 & 0 & 0 & 0 & 0 & 0 & 0 & 0 & 0 & 0 & 0 & 0 & 0 & 0 & 0 \\
\hline P19 & 0 & 0 & 0 & 0 & 1 & 0 & 0 & 0 & 0 & 0 & 0 & 0 & 0 & 0 & 0 & 0 & 0 & 0 \\
\hline $\mathrm{P} 20$ & 0 & 1 & 0 & 0 & 0 & 0 & 0 & 0 & 1 & 0 & 0 & 0 & 0 & 1 & 0 & 1 & 0 & 0 \\
\hline
\end{tabular}

$f_{i j}=$ frequency/volume of movement between machines i \& j

$\mathrm{c}_{\mathrm{ij}}=$ cost to move one unit load per one distance unit between two machines $\mathrm{d}_{\mathrm{ij}}=$ distance between machine $\mathrm{i}$ and $\mathrm{j}$.

Assuming the cost $\mathrm{c}_{\mathrm{ij}}$ as constant (Rs 10/per meter) the objective would be reduced to minimize the total distance traveled for the parts. In this problem, there are 4 cells formed. Intra-cell design of cell 1

Fig. 3 shows the

Table 5. Cells \& their corresponding machines

\begin{tabular}{|c|c|c|}
\hline $\begin{array}{c}\text { Cell } \\
\text { No }\end{array}$ & $\begin{array}{c}\text { Machines in } \\
\text { each cell }\end{array}$ & $\begin{array}{c}\text { Parts processed in each } \\
\text { cell }\end{array}$ \\
\hline 1 & $\mathrm{~L} 1, \mathrm{~L} 7, \mathrm{~L} 8, \mathrm{D} 1, \mathrm{D} 2$ & $\mathrm{P} 1, \mathrm{P} 3, \mathrm{P} 4, \mathrm{P} 12, \mathrm{P} 14, \mathrm{P} 15, \mathrm{P} 16$ \\
\hline 2 & $\mathrm{~L} 6, \mathrm{M} 1, \mathrm{G} 1, \mathrm{BR}, \mathrm{BA}$ & $\mathrm{P} 6, \mathrm{P} 10, \mathrm{P} 11, \mathrm{P} 12, \mathrm{P} 13$ \\
\hline 3 & $\mathrm{~L} 3, \mathrm{~L} 4, \mathrm{D} 3$ & $\mathrm{P} 2, \mathrm{P} 5, \mathrm{P} 8, \mathrm{P} 18$ \\
\hline 4 & $\mathrm{~L} 2, \mathrm{~L} 5, \mathrm{~L} 9, \mathrm{M} 2, \mathrm{G} 2$ & $\mathrm{P} 7, \mathrm{P} 9, \mathrm{P} 17$, ,P19, P20 \\
\hline
\end{tabular}

problem is to minimize cost function and it is mapped to a score function. An evaluation function assigns a real number to measure the fitness of each chromosome. Reproduction selection is used to select chromosomes to be exposed to genetic operations. The 'Roulette wheel' approach is used to select chromosomes in accordance with their fitness values. Crossover is the diversification mechanism which enables GA to examine

unvisited regions and to generate solutions that differ in various significant ways from those seen before. The string to be crossed and the crossing points are selected randomly. The two- point crossover has been adopted in this study. Mutation is the 'exploration operator' and used as a mechanism for intensification. During intensification, the search focuses on examining neighbors of possible solutions. Applying crossover and mutations lead to generation of neighborhoods.

\section{The objective function}

Deb and Bhattacharyya (2005) used the following equation (Eqn. 1) in their computerized facility layout problem. The objective function is formulated as minimizing the total transportation cost, which is achieved by minimizing the total travel distance of parts.

$$
\text { Obj }=\min \sum_{i=1}^{N} \sum_{j=1}^{N} f_{i j} c_{i j} d_{i j}
$$

Where, initial design of cell 1 . The absolute co-ordinate distance in meters for each machine from location 1 is indicated in Table 6. The frequency of part movements between each machine are shown in Table 7 . The distance matrix arrived through the program is mentioned in Table 8. The modified machine location after applying GA is depicted in Table 9.

\section{Intra-cell design of cell 2}

Fig. 4 shows the initial design of cell 2. The coordinate distance of each machine from location 1 is indicated in Table 10 in terms of meters. The frequency of part movements between each machine is denoted in Table 11. The distance matrix arrived through the program is mentioned in Table 12. The modified machine location (one optimum alternative) after applying GA is depicted in Table 13.

Intra-cell design of cell 3

In cell 3 , the arrangement of machines are not altered since there are only 3 machines in the cell which gives the same material handling cost for all possible combinations.

Intra-cell design of cell 4

The initial design of cell 4 is shown in Fig. 5. The co-ordinate distance of each machine from location 1 is indicated in Table 14 in terms of
Table 6 . Absolute co-ordinate locations of machines in meters for cell 1

\begin{tabular}{|c|c|c|}
\hline Machine & $\mathrm{X}$ & $\mathrm{Y}$ \\
\hline L1 & 0 & 0 \\
\hline L7 & 6 & 0 \\
\hline L8 & 9 & 4 \\
\hline D1 & 3 & 4 \\
\hline D2 & 3 & 4 \\
\hline
\end{tabular}
meters. Table 15 shows the details of the frequency of part movements between each machine. Table 16 shows the distance matrix arrived through the program. The modified machine location after applying GA for cell 4 (optimum alternative) is depicted in Table 17.
Research article

CIndian Society for Education and Environment (iSee)
"Virtual cellular layout" http://www.indjst.org
Table 7. Frequency matrix for cell 1

\begin{tabular}{|l|l|l|l|l|l|}
\hline & L1 & L7 & L8 & D1 & D2 \\
\hline L1 & 0 & 1 & 1 & 2 & 0 \\
\hline L7 & 0 & 0 & 1 & 2 & 0 \\
\hline L8 & 0 & 0 & 0 & 1 & 1 \\
\hline D1 & 0 & 0 & 0 & 0 & 0 \\
\hline D2 & 0 & 0 & 0 & 0 & 0 \\
\hline
\end{tabular}

Jayachitra \& Prasad Indian J.Sci.Technol. 


\section{Comparison of material handling cost}

Table 18 shows the material handling cost comparison of producing one batch of each part type through existing and modified arrangement of machines in cells.

\section{Simulation of cellular layout}

The Cellular layout in which the machine types belonging to a particular cell are located closely is formed through ROC and modeled in WITNESS simulation package. The nine experimental combinations of cellular layout models are designed. All the operations of the parts in specific part family are processed within a cell. In few cases inter-cellular movements are allowed because of exceptional elements. Fig. 6 shows cellular layout model used for simulation.

Simulation of virtual cellular layout

The layout of virtual cellular manufacturing model (Fig. 7) is similar to process layout but the machines are temporarily dedicated to a particular part family. There is a logical grouping of machines on the basis of ROC algorithm. The routing of parts is given in such a way that they will only loaded to the machine which is dedicated for its operation i.e. each

operation of a part type can be processed only on a specific machine in a group of similar machines. All the nine combinations of virtual cellular layout are modeled and simulated.

Results and discussion

All the twenty seven models are simulated for a period of one month. The performance measures namely average percentage machine utilization, throughput, distance traveled by parts and average work-inprocess are recorded for process, cellular and virtual cellular layouts and are presented in Tables 19, 20 \& 21 respectively. The outputs obtained from the simulation of 27 experiments in WITNESS simulation software are used as inputs to MINITAB for statistical analysis. The results of the MINITAB gives the inference for each performance measure and the same are presented in the following paragraphs.

\section{Percentage machine utilization}

From Fig. 8, the following conclusions are arrived. The average percentage machine utilization seems to be maximum for the combination of cellular layout, lot size of 4 and the scheduling rule FIFO. Higher machine Research article

CIndian Society for Education and Environment (iSee)
Table 8. Distance matrix for cell 1

\begin{tabular}{|c|c|c|c|c|c|}
\hline & $\mathrm{L} 1$ & $\mathrm{~L} 7$ & $\mathrm{~L} 8$ & $\mathrm{D} 1$ & $\mathrm{D} 2$ \\
\hline $\mathrm{L} 1$ & 0 & 6 & 9.8 & 5 & 5 \\
\hline $\mathrm{L} 7$ & 6 & 0 & 5 & 5 & 5 \\
\hline $\mathrm{L} 8$ & 9.8 & 5 & 0 & 6 & 6 \\
\hline $\mathrm{D} 1$ & 5 & 5 & 6 & 0 & 0 \\
\hline $\mathrm{D} 2$ & 5 & 5 & 6 & 0 & 0 \\
\hline
\end{tabular}

Table 9. Optimum arrangement of machines in cell 1

utilization can be achieved in the order of cellular, virtual cellular and process layouts in case of layout type, FIFO, LPT and SPT in case of scheduling rule and 4,5 and 6 in case of lot size. The higher machine utilization of cellular and virtual cellular layouts is due to dedication of

machines to a particular part family which requires reduced setup time.

\section{Throughput}

From Fig. 9, it is observed that the

Table 10

Absolute co-ordinate locations of machines in meters for cell 2

\begin{tabular}{|c|c|c|}
\hline Machine & $\mathrm{X}$ & $\mathrm{Y}$ \\
\hline L6 & 0 & 0 \\
\hline M1 & 3 & 0 \\
\hline G1 & 6 & 2 \\
\hline BR & 3 & 4 \\
\hline BA & 0 & 4 \\
\hline
\end{tabular}

Table 11. Frequency matrix for cell 2

\begin{tabular}{|l|l|l|l|l|l|}
\hline & L6 & M1 & G1 & BR & BA \\
\hline L6 & 0 & 1 & 1 & 0 & 2 \\
\hline M1 & 0 & 0 & 2 & 1 & 1 \\
\hline G1 & 0 & 0 & 0 & 1 & 1 \\
\hline BR & 0 & 0 & 0 & 0 & 0 \\
\hline BA & 0 & 0 & 0 & 0 & 0 \\
\hline
\end{tabular}

Table 12. Distance matrix for cell 2

\begin{tabular}{|c|c|c|c|c|c|}
\hline & L6 & M1 & G1 & BR & BA \\
\hline L1 & 0 & 3 & 6.3 & 5 & 4 \\
\hline G1 & 3 & 0 & 3.6 & 4 & 5 \\
\hline BR & 5 & 4.6 & 0 & 3.6 & 6.3 \\
\hline BA & 4 & 5 & 6.6 & 0 & 3 \\
\hline
\end{tabular}

Table 13. Optimum arrangement of machines in cell 2

\begin{tabular}{|l|c|c|c|c|c|}
\multicolumn{7}{c}{ machines in cell 2} \\
\hline Location & 1 & 2 & 3 & 4 & 5 \\
\hline Machine & M1 & BR & G1 & L6 & BA \\
\hline
\end{tabular}
maximum throughput is achieved through the combination of cellular layout, lot size of 4 and FIFO scheduling rule. The scheduling rules are in the order of FIFO, LPT and SPT in case of higher throughput. The lot size of 4 gives maximum throughput in all cases. It is obvious that the higher utilization of machines in cellular and virtual cellular layouts leads to higher throughput.

\section{Distance traveled by parts}

It is evident that the distance traveled by parts is minimum in the combination of cellular layout, and lot size of 6 (Fig. 10). The scheduling rule is not having much influence on this measure. There is not much difference in distance traveled by parts in virtual cellular and process layouts. The lesser distance traveled by

parts in case of cellular layout is due to the assignment of part families to their corresponding machine cell and hence there will be very few inter-cell movement of parts.

Work-in-process

From Fig. 11, it is observed that the minimum work-in-process is achieved through process layout, lot size 5 and LPT scheduling rule. The layouts are in the order of process, virtual cellular and cellular and the scheduling rules are in the order of LPT, SPT and FIFO and lot sizes are in the order of 5,6 and 4 in case of minimum work-inprocess.

\section{Comparative study}

Table 14. Absolute coordinate locations of machines in meters for cell 4

\begin{tabular}{|c|c|c|}
\hline Machine & $\mathrm{X}$ & $\mathrm{Y}$ \\
\hline L2 & 0 & 0 \\
\hline L5 & 6 & 0 \\
\hline L9 & 9 & 4 \\
\hline M2 & 3 & 4 \\
\hline G2 & 3 & 4 \\
\hline
\end{tabular}

"Virtual cellular layout" http://www.indjst.org
The performance measure of all three layouts is shown in Table 22. The comparison of performance measures of cellular and virtual cellular layouts with that of existing process layout in terms of percentage increase / decrease is shown in Table 23.

\section{Conclusion}

After grouping the parts into part families and machines into machine cells, the material movement in the production line is decreased from $921 \mathrm{~m}$ to $513 \mathrm{~m}$ which shows a reduction

Jayachitra \& Prasad Indian J.Sci.Technol. 
of $44.29 \%$. The throughput of the production line is increased by $36.47 \%$ in case of cellular layout and in case of virtual cellular layout an increase of $23.19 \%$ is achieved when compared with the existing process layout. The machines in the existing process layout

are underutilized and it is increased by $43.78 \%$ in cellular layout and $35.48 \%$ in virtual cellular layout. There is no much significant

change in the work-in-process in all the three layouts. The results obtained from the WITNESS simulation software shows that, cellular layout gives better output than the virtual cellular layout and the process layout. But the output of virtual cellular layout lies in between the cellular layout and that of the process layout.

Table 18. Comparison of material handling cost of existing arrangement with the modified arrangement

\begin{tabular}{|c|c|c|c|c|}
\hline \multirow{2}{*}{ Cell } & \multicolumn{2}{|c|}{ Arrangement of machines } & \multicolumn{2}{c|}{$\begin{array}{c}\text { Material handling } \\
\text { Cost (Rs) }\end{array}$} \\
\cline { 2 - 5 } & Existing & Altered & Existing & Altered \\
\hline 1 & $\mathrm{~L} 1, \mathrm{~L} 7, \mathrm{~L} 8, \mathrm{D} 1, \mathrm{D} 2$ & $\mathrm{D} 1, \mathrm{~L} 8, \mathrm{~L} 1, \mathrm{D} 2, \mathrm{~L} 7$ & 308 & 210 \\
\hline 2 & $\mathrm{~L} 6, \mathrm{M} 1, \mathrm{G} 1, \mathrm{BR}, \mathrm{BA}$ & $\mathrm{M} 1, \mathrm{BR}, \mathrm{G} 1, \mathrm{~L} 6, \mathrm{BA}$ & 289 & 252 \\
\hline 3 & $\mathrm{~L} 3, \mathrm{~L} 4, \mathrm{D} 3$ & $\mathrm{L3}, \mathrm{L} 4, \mathrm{D} 3$ & 100 & 100 \\
\hline 4 & $\mathrm{~L} 2, \mathrm{~L} 5, \mathrm{~L} 9, \mathrm{M} 2, \mathrm{G} 2$ & $\mathrm{~L} 2, \mathrm{G} 2, \mathrm{M} 2, \mathrm{~L} 5, \mathrm{~L} 9$ & 418 & 260 \\
\hline
\end{tabular}

Table 15. Frequency matrix for cell 4

\begin{tabular}{|c|c|c|c|c|c|}
\hline & L2 & L5 & L9 & M2 & G2 \\
\hline L2 & 0 & 0 & 0 & 0 & 1 \\
\hline L5 & 0 & 0 & 0 & 1 & 0 \\
\hline L9 & 0 & 0 & 0 & 0 & 2 \\
\hline M2 & 0 & 0 & 0 & 0 & 0 \\
\hline G2 & 0 & 0 & 0 & 0 & 0 \\
\hline
\end{tabular}

Table 16. Distance matrix for cell 4

\begin{tabular}{|c|c|c|c|c|c|}
\hline & L2 & L5 & L9 & M2 & G2 \\
\hline L2 & 0 & 6 & 9.8 & 5 & 5 \\
\hline L5 & 6 & 0 & 5 & 5 & 5 \\
\hline L9 & 9.8 & 5 & 0 & 6 & 6 \\
\hline M2 & 5 & 5 & 6 & 0 & 0 \\
\hline G2 & 5 & 5 & 6 & 0 & 0 \\
\hline
\end{tabular}

Table 17. Optimum arrangement of machines in cell 4

\begin{tabular}{|l|c|c|c|c|c|} 
Location & 1 & 2 & 3 & 4 & 5 \\
\hline
\end{tabular}

The implementation of cellular layout is more appropriate than the other two layouts for the industry considered for study. But the primary disadvantage in implementing cellular layout is that, it requires re-location of resources based on cell formation and part grouping. Also based on the part mix variations/new part introductions, this practice have to be carried out repeatedly. Hence the viable alternative for the above scenario is suggested as virtual cellular layout, which also has much better performance than process layout. The implication in the transformation of a process layout into virtual cellular layout is that the industry has to reorganize their production scheme by the way of introducing new part coding (based on group technology principle), identification of machine groupings and some changes in scheduling. Also proper guideline is to be given to the operators in this regard.

The simulation experiments are conducted for the static demand inputs. If we analyze the dynamic demand conditions, more insight can be obtained on the layout performances.

\section{References}

Table 19. Performance measures for process layout

\begin{tabular}{|l|l|l|l|l|l|l|l|l|l|}
\hline Scheduling rule & FIFO & FIFO & FIFO & SPT & SPT & SPT & LPT & LPT & LPT \\
\hline \multicolumn{1}{|c|}{ Lot size } & 4 & 5 & 6 & 4 & 5 & 6 & 4 & 5 & 6 \\
\hline $\begin{array}{l}\text { Average machine } \\
\text { utilization (\%) }\end{array}$ & 17.65 & 16.85 & 17.63 & 16.05 & 15.19 & 14.88 & 16.69 & 15.88 & 16.83 \\
\hline Throughput & 5996 & 5714 & 5994 & 5338 & 5194 & 5032 & 5521 & 5370 & 5714 \\
\hline $\begin{array}{l}\text { Distance traveled } \\
\text { by parts (m) }\end{array}$ & 1121 & 897 & 746 & 1121 & 897 & 746 & 1121 & 897 & 746 \\
\hline Average WIP & 2139 & 2134 & 2143 & 2187 & 2134 & 2130 & 2123 & 2111 & 2133 \\
\hline
\end{tabular}

Table 20. Performance measures for cellular layout

\begin{tabular}{|c|c|c|c|c|c|c|c|c|c|}
\hline Scheduling rule & FIFO & FIFO & FIFO & SPT & SPT & SPT & LPT & LPT & LPT \\
\hline Lot size & 4 & 5 & 6 & 4 & 5 & 6 & 4 & 5 & 6 \\
\hline $\begin{array}{c}\text { Average machine } \\
\text { utilization }(\%)\end{array}$ & 27.16 & 23.3 & 23.82 & 22.7 & 21.49 & 22.91 & 25.69 & 23.47 & 21.7 \\
\hline Throughput & 8473 & 7895 & 7561 & 7543 & 7155 & 7017 & 7796 & 7420 & 7203 \\
\hline $\begin{array}{c}\text { Distance traveled } \\
\text { by parts }(\mathrm{m})\end{array}$ & 625 & 500 & 416 & 625 & 500 & 416 & 625 & 500 & 416 \\
\hline Average WIP & 2201 & 2189 & 2182 & 2178 & 2170 & 2168 & 2184 & 2176 & 2172 \\
\hline
\end{tabular}

Table 21. Performance measures for virtual cellular layout

\begin{tabular}{|l|c|c|c|c|c|c|c|c|c|}
\hline Scheduling rule & FIFO & FIFO & FIFO & SPT & SPT & SPT & LPT & LPT & LPT \\
\hline Lot size & 4 & 5 & 6 & 4 & 5 & 6 & 4 & 5 & 6 \\
\hline $\begin{array}{l}\text { Average machine } \\
\text { utilization (\%) }\end{array}$ & 23.93 & 23.58 & 21.67 & 21.77 & 22.82 & 20.02 & 22.73 & 22.8 & 20.69 \\
\hline Throughput & 7585 & 7148 & 6859 & 6754 & 6480 & 6368 & 6984 & 6718 & 6538 \\
\hline $\begin{array}{l}\text { Distance traveled } \\
\text { by parts (m) }\end{array}$ & 1119 & 895 & 746 & 1119 & 895 & 746 & 1119 & 895 & 746 \\
\hline Average WIP & 2179 & 2170 & 2164 & 2156 & 2151 & 2148 & 2162 & 2126 & 2154 \\
\hline
\end{tabular}

Research article

CIndian Society for Education and Environment (iSee)
"Virtual cellular layout" http://www.indjst.org
1. Adil GK and Rajamani D (2000) The trade-off between intra-cell and inter-cell moves in group technology cell formation. J. Manufac. Sys.19(5), 305-317.

2. Ahi A, Aryanezhad MB, Ashtiani B and Makui A (2009) A novel approach to determine cell formation, intracellular machine layout and cell layout in the CMS problem based on Topsis method. Computers Opera. Res. 36(5), 14781496.

3. Babu A, Nandurkar KN and Thomas A (2000) Development of virtual cellular manufacturing systems for SMEs. Int. J. Logistics Information Management. 13(4), 228-242.

4. Balakrishnan $\mathrm{J}$ and Hung Cheng C (2007) Multi-period planning and Jayachitra \& Prasad Indian J.Sci.Technol. 
uncertainty issues in cellular manufacturing: A review and future directions. European J Operational Res. 177(1), 281-309.

5. Baykssoglu A and Gindy N (2000) MOCACEF 1.0: Multiple objective capability based approach to form part-machine groups for cellular manufacturing application. Int. J. Production Res. 38(5), pp1133-1161.

6. Chandrasekharan MP and Rajagopalan R (1986a) An ideal seed non-hierarchical clustering algorithm for cellular manufacturing. Int. J. Production Res. 24(2), 451464.

7. Chandrasekharan MP and Rajagopalan R (1986b) MODROC: an extension of rank order clustering for group technology. Int. J. Production Res. 24(5), 1221-1233.

8. Deb $S$ and Bhattacharyya $B$ (2005) Fuzzy decision support system for manufacturing facilities layout planning. Dec. Support Sys. 40(2), 305 -314.

\begin{tabular}{|c|c|r|c|}
\hline \multirow{2}{*}{ Table 22. Performance measures of layouts } \\
\cline { 2 - 4 } $\begin{array}{c}\text { Performance } \\
\text { measures }\end{array}$ & $\begin{array}{r}\text { Proces } \\
\text { s }\end{array}$ & $\begin{array}{r}\text { Virtual } \\
\text { cel } \\
\text { lul } \\
\text { ar }\end{array}$ & $\begin{array}{r}\text { cellula } \\
\mathrm{r}\end{array}$ \\
\hline \begin{tabular}{c} 
Throughput (Nos) \\
\hline $\begin{array}{c}\text { Total distance } \\
\text { traveled by } \\
\text { parts (m) }\end{array}$
\end{tabular} & 5541 & 6826 & 7562 \\
\hline $\begin{array}{c}\text { Average M/C } \\
\text { utilization (\%) }\end{array}$ & 16.40 & 22.22 & 23.58 \\
\hline $\begin{array}{c}\text { Average WIP } \\
\text { (Nos) }\end{array}$ & 2137 & 2156 & 2180 \\
\hline
\end{tabular}

Vol. 3 No. 4 (Apr. 2010)

ISSN: 0974- 6846

An industrial application. $J$. Intelligent Manufacturing. 1(3), 185-191.

16. Hyer $\mathrm{N}$ and Wemmerlöv $\mathrm{U}$ (2002) Reorganizing the factory: Competing through cellular manufacturing. Productivity press, Portland, OR.

17. Irani SA, Cavalier TM and Cohen PH (1993) Virtual manufacturing cells: exploiting layout design and inter-cellular flows for the machine sharing problem. Int. J. Production Res. 31(4), 791-810.

increase/decrease in performance measure of cellular and virtual cellular layouts in comparison with existing process layout

\begin{tabular}{|l|c|c|}
\hline \multirow{2}{*}{$\begin{array}{c}\text { Performance } \\
\text { measures }\end{array}$} & $\begin{array}{c}\text { Virtual } \\
\text { cell } \\
\text { ular }\end{array}$ & Cellular \\
\hline Throughput & 23.19 & 36.47 \\
\hline $\begin{array}{c}\text { Total distance } \\
\text { traveled by } \\
\text { parts (m) }\end{array}$ & 0 & 44.29 \\
\hline $\begin{array}{c}\text { Average M/C } \\
\text { utilization (\%) }\end{array}$ & 35.48 & 43.78 \\
\hline Average WIP & 1 & 2 \\
\hline
\end{tabular}

18. Kanan VR and Ghosh S (1996) Cellular manufacturing using virtual cells. Int. J. Operations Production Management. 16(5), 99-112.

19. Kaparthi S and Suresh NC (1994) Performance of selected part-machine grouping techniques for data sets of wide ranging sizes and imperfection. Decision Sci. 25(4), 515-539.

20. Kesen SE, Toksari MD, Güngör Z and Güner E (2009) Analyzing the behaviors of virtual cells (VCs) and traditional manufacturing systems: Ant colony optimization (ACO)-based meta models. Computers Operations Res. arch. 36(7), 2275-2285.

21. King JR (1980) Machine-component grouping in production flow analysis: an approach using a rank order clustering algorithm. Int. J. Production Res. 18(2), 213 - 232.

22. Luong LHS, Hsu HY, Rae T and Kubank D (1997) Applications of cellular manufacturing for batch production: A case study. Proc. of the world congress on Manufac. Technol. Cairns, Australia. pp117-124.

23. Mahmoodi F, Dooley KJ and Starr PJ (1990) An investigation of dynamic group scheduling heuristics. Int. J. Production Res. 28(9), 1695-711.

24. Mak KL, Peng P, Wang XX and Lau TL (2007) An ant colony optimization algorithm for scheduling virtual cellular manufacturing systems. Int. J. Computer Integrated Manufac. 20(6), 524 - 537.

25. McLean CR, Bloom HM and Hopp TH (1982) The virtual manufacturing cell. Proc. of $4^{\text {th }}$ IFAC/IFIP conf. on information control problems in manufac. Technol. pp105-111.

26. Morris JS and Tersine RJ (1990) A simulation analysis of factors influencing the attractiveness of
Research article

CIndian Society for Education and Environment (iSee)
"Virtual cellular layout" http://www.indjst.org
Jayachitra \& Prasad Indian J.Sci.Technol. 
group technology cellular layouts. Management Sci. 36(12), 1567-78.

27. Nomden G and van der Zee DJ (2008) Virtual cellular manufacturing: Configuring routing flexibility. Int. J. Production Economics. 112(1), 439 - 451.

28. Peng YF, Guan ZL, Ma I, Zhang CY and Li PG (2009) A two-stage mathematical approach for the design of virtual manufacturing cells. Int. J. Mechatronics Manufac. Sys. 2(1/2), 80 - 96.

29. Rajamani D, Singh N and Aneja $Y$ (1990) Integrated design of cellular manufacturing systems in the presence of alternatives process plans. Int. J. Production Res. 28(8), 1541-1554.

30. Rajamani D, Singh N and Aneja Y (1996) Design of cellular manufacturing systems. Int. J. Production Res. 34(7), 1917-1928.

31. Saad SM and Lassila AM (2006) An integrated approach for shop floor configuration in fractal manufacturing systems. Int. J. Services Operations Management. 2(2), 109 -123.

32. Schaller J (2005) Tabu search procedures for the cell formation problem with intra-cell transfer costs as a function of cell size. Computers Industrial Engg. 49(3), 449 - 462.

33. Shiba S, Graham A and Walden D (1993) A new American TQM, four practical revolutions in management, Portland, OR, Productivity press.

34. Sofianopoulou S (2010) Formation of manufacturing cells in group technology using a genetic algorithm approach. Int. J. Industrial Sys. Engg. 5(2), 212-225.

35. Song S and Hitomi K (1992) Group technology cell formation for minimizing the inter-cell parts flow. Int. J. Production Res. 30(12), 2737-2753.

36. Souilah A, Mecheri $Y$ and Bennesroune A (1996) Intra-cell layout design: a combinatorial optimisation approach. Int. conf. on new information technologies in education. Minsk, pp123-130.

37. Srinivasan G, Narendran TT and Mahadevan B (1990) An assignment model for the part-families problem in group technology. Int. J. Production Res. 28(1), 145-52.

38. Stanfel LE (1989) A successive approximations method for a cellular manufacturing problem. Ann. Operations Res. 17(1), 13-30

39. Suresh NC (1992) Partitioning work centers for group technology: analytical extension and shop level simulation investigation. Decision Sci. 23(2), 267-290.

40. Vakharia AJ and Wemmerlöv U (1990) Designing a cellular manufacturing system: a material flow approach based on operation sequences. IIE Trans. 22(1), 84-97.

41. Venugopal $V$ and Narendran TT (1992) A genetic algorithm approach to the machine-component grouping problem with multiple objectives. Computers Industrial Engg. 22(4), 469-480.

42. Waterson PE, Clegg CW, Bolden R, Pepper K, Warr PB and Wall TD (1999) The use and effectiveness of
Vol. 3 No. 4 (Apr. 2010)

ISSN: 0974- 6846

modern manufacturing practices: A survey of UK industry. Int. J. Production Res. 37(10), 2271-2292.

43. Wei NC and Mejabi OO (2008) A clustering approach for minimizing inter-cell trips in cell formation. $J$. Intelligent Manufac. 19(1), 13-20.

44. Wemmerlöv U and Danny Jonson J (2004) Why does cell implementation stop? Factors influencing cell penetration in manufacturing plants. Production Operations Management. 13(3), 272-289. "Virtual cellular layout"
http://www.indjst.org
Jayachitra \& Prasad Indian J.Sci.Technol. 